\title{
PENINGKATAN MINAT DAN HASIL BELAJAR MATEMATIKA MATERI SEGIEMPAT DAN SEGITIGA MENGGUNAKAN MODEL PEMBELAJARAN (PAIKEM GEMBROT) PADA PESERTA DIDIK KELAS VII-D MTS NEGERI SALATIGA
}

\author{
Esti Rahayuningtyas ${ }^{1}$, Muhammad Istiqlal ${ }^{2}$ \\ 1,2Program Studi Tadris Matematika IAIN Salatiga, Indonesia \\ esti2574@gmail.com
}

\begin{abstract}
This research aimed to increase the interest mathemathics learning and student achievement of class VII-D MTs $N 1$ Salatiga used PAIKEM Gembrot type.the types of research was Classroom Action Research (CAR). Research was conducted minimal two cycles action. Data wa collected by questionnair, observation, interview, test and documentation.result showed an increase student interest viewed from questionnair, observation, interview and test. Student achievement incresed to by 42,89 at pre-cycle to 85,53 in cycle I and incresed to 90,53 in cycle II. Therefore suggested to teachers use the PAIKEM Gembrot type to increase student interest and achievement.
\end{abstract}

\section{PENDAHULUAN}

Mata pelajaran matematika merupakan mata pelajaran yang sangat diperlukan. Matematika berfungsi sebagai alat yang digunakan dalam berbagai ilmu kehidupan. Pada umumnya matematika dianggap sebagai mata pelajaran yang sulit untuk dimengerti oleh peserta didik sehingga peserta didik terlebih dahulu takut terhadap mata pelajaran matematika. Para peserta didik beranggapan bahwa matematika identik dengan rumus-rumus dan angka saja yang dianggap kurang bermanfaat bagi kehidupan peserta didik. Padahal kalau dicermati setiap segi kehidupan manusia tidak lepas dari matematika dan pada gilirannya akan mempermudah dalam pemecahan masalah. Sebagai contoh, seorang tukang bangunan ketika akan memasang ubin suatu ruangan jika tidak mengetahui ilmu matematika atau lebih tepatnya dalam materi segiempat ini, maka tukang tersebut akan kesulitan dalam menentukan jumlah ubin yang dibutuhkan pada suatu ruangan tersebut.

Masalah pembelajaran matematika juga terjadi di MTs Negeri Salatiga, hal ini diketahui berdasarkan hasil wawancara dengan guru matematika MTs Negeri Salatiga bahwa minat dan hasil belajar matematika masih rendah dibanding dengan mata pelajaran lainnya. Rendahnya minat belajar dapat dilihat ketika proses pembelajaran berlangsung, peserta didik terlihat pasif dan proses pembelajaran hanya terjadi satu arah yaitu dari guru ke peserta didik. Rendahnya hasil belajar ditandai dengan banyaknya peserta didik yang belum mencapai KKM.

Berdasarkan hasil diskusi antara peneliti dan guru matematika bahwa faktor penyebab rendahnya minat dan hasil belajar peserta didik di MTs Negeri Salatiga diantaranya, guru kurang inovatif dan kreatif dalam penggunaan model pembelajaran, bahkan sebagian besar materi disampaikan dengan menggunakan model pembelajaran ekspositori, guru kurang memanfaatkan media pembelajaran. Dalam proses pembelajaran guru lebih sering menggunakan papan tulis dan buku sebagai media pembelajaran, guru kurang bisa mengaktifkan suasana kelas, sistem pembelajaran yang digunakan masih bersifat individual tidak berkelompok, pola pembelajaran yang diterapkan guru masih satu arah yaitu interaksi dari guru ke peserta didik dan guru lebih mengejar untuk materi selesai ketimbang pemahaman peserta didik.

Untuk menyelesaikan masalah tersebut, maka perlu dicarikan suatu 
kegiatan pembelajaran yang tepat supaya dapat meningkatkan minat dan hasil belajar matematika peserta didik. Salah satu alternatif yang bisa dilakukan adalah penggunaan model pembalajaran yang kreatif, inovatif dan dapat menarik minat peserta didik dalam mempelajari matematika. Disini peneliti memberikan alternatif model pembelajaran PAIKEM Gembrot (Pembelajaran Aktif Inovatif Kreatif Efektif Menyenangkan Gembira dan Berbobot).

\section{METODE}

Penelitian tindakan kelas ini dilaksanakan di kelas VII-D MTs Negeri Salatiga Kecamatan Argomulyo Kota Salatiga. pada tanggal 9 April sampai dengan 18 April Tahun 2019. Penelitian dilaksanakan dalam 2 siklus, dimana masing-masing siklus terdiri dari 2 pertemuan. Penelitian ini menggunakan jenis Penelitian Tindakan Kelas (PTK). PTK merupakan suatu pencermatan terhadap kegiatan belajar yang berupa sebuah tindakan, yang sengaja dimunculkan dan terjadi dalam sebuah kelas secara bersama. PTK merupakan suatu tindakan yang bersifat reflektif oleh para pelaku tindakan, dilakukan untuk meningkatkan kemantapan rasional mengenai tindakan mereka dalam bertugas, memperdalam pemahaman terhadap tindakan-tindakan yang dilakukannya itu, serta memperbaiki kondisi dimana praktik pembelajaran dilaksanakan.

Subjek penelitian ini adalah peserta didik kelas VII-D MTs Negeri Salatiga Kecamatan Argomulyo Kota Salatiga tahun pelajaran 2018/2019, yang terdiri dari 38 peserta didik dengan rincian jumlah peserta didik laki-laki sebanyak 15 peserta didik, dan jumlah didik perempuan sebanyak 23 peserta didik. Sedangkan objek penelitian ini adalah minat dan hasil belajar matematika dengan menggunakan model PAIKEM Gembrot.
Teknik pengumpulan data yang digunakan dalam penelitian ini adalah dengan angket, pengamatan atau observasi, wawancara, tes dan dokumentasi foto. Angket dalam penelitian ini digunakan untuk mengukur minat belajar peserta didik pada proses pembelajaran yang dilakukan. Pada penelitian ini, angket diberikan kepada peserta didik sebanyak 3 kali yaitu prasiklus, tes siklus I, dan tes siklus II. Observasi pada penelitian ini dimaksudkan oleh peneliti untuk melakukan pengamatan terhadap keterlaksanaan model pembelajaran PAIKEM Gembrot yang dilakukan oleh guru dan aktivitas belajar peserta didik. Wawancara dalam penelitian ini digunakan untuk mengetahui kondisi awal peserta didik dan mengetahui respon peserta didik terhadap poses pembelajaran yang dilakukan oleh guru. Tes digunakan untuk memperoleh data mengenai peningkatan hasil belajar peserta didik melalui instrumen berupa soal-soal tes pilihan ganda. Metode dokumentasi foto merupakan suatu cara memperoleh data mengenai hal-hal tertntu terutama peninggalan tertulis, arsip-arsip dan sebagaimana yang berkaitan dengan subyek yang diteliti.

Pada analisis data ini dapat dilakukan dengan menggunakan analisis dan refleksi dalam setiap siklusnya berdasarkan hasil penelitian yang berupa hasil pada tes dan lembar pengamatan lainnya. Arikunto (2014:131) mengemukakan bahwa jenis data yang digunakan dalam penelitian tindakan kelas ada dua jenis yaitu data kuantitatif dan data kualitatif.

Data kuantitatif berupa hasil belajar peserta didik yang dapat dianalisis secara deskriptif dengan menggunakan analisis statistik deskriptif. Di dalam penelitian ini, ada 4 macam nilai yang harus dihitung yaitu : Menghitung nilai rata-rata minat belajar kelas yang diteliti; Ketuntasan klasikal minat belajar, jumlah peserta didik yang memiliki minat belajar tinggi dan sedang lebih dari $50 \%$ dari jumlah total 


\section{Jurnal Hipotenusa, 1 (1), Desember 2019}

Esti Rahayuningtyas, Muhammad Istiqlal

peserta didik dalam satu kelas. Menghitung nilai rata-rata hasil belajar kelas yang diteliti; dan Ketuntasan klasikal hasil belajar, persentase ketuntasan klasikal merupakan hasil belajar peserta didik $\geq 85 \%$ dari jumlah total peserta didik dalam satu kelas mendapat nilai $\geq 73$.

Data kualitatif yaitu data yang berupa informasi dalam bentuk narasi yang digunakan untuk menjawab permasalahan mengenai peningkatan minat dan hasil belajar matematika materi segiempat dan segitiga menggunakan model Pembelajaran Aktif Inovatif Kreatif Efektif Menyenangkan Gembira Berbobot (PAIKEM Gembrot) pada Peserta Didik Kelas VII-D MTs Negeri Salatiga Kecamatan Argomulyo Kota Salatiga Tahun Pelajaran 2018/2019.

\section{HASIL DAN PEMBAHASAN}

Hasil peningkatan minat belajar peserta didik dihitung menggunakan lembar angket observasi dan lembar observasi. Peningkatan minat belajar peserta didik dari hasil data angket minat peserta didik setelah tindakan antar siklus dapat dilihat pada tabel 1.

Tabel 1. Peningkatan Skor Minat Belajar Hasil Angket

\begin{tabular}{|c|c|c|c|}
\hline No. & Siklus & $\begin{array}{c}\text { Skor } \\
\text { Minat }\end{array}$ & Kualifikasi \\
\hline 1. & Pertama & 46,16 & Sedang \\
2. & Kedua & 51,42 & Tinggi \\
\hline \multicolumn{2}{|c|}{ Peningkatan } & \multicolumn{2}{|c|}{5,26} \\
\hline \multicolumn{2}{|c|}{ Persentase } \\
Peningkatan
\end{tabular}

Peningkatan minat belajar peserta didik dari hasil data angket minat belajar peserta didik setelah diadakan tindakan dapat dilihat pada tabel 1. Berdasarkan tabel 1 diperoleh bahwa terjadi peningkatan minat belajar peserta didik hasil perhitungan angket sebesar 5,26 atau meningkat 28,95\% dari siklus I ke siklus II.

Sedangkan hasil belajar peserta didik dapat dilihat dari nilai ketuntasan yang diperoleh peserta didik dari evaluasi nilai awal (pra sikls) ke siklus I dan ke siklus II, lihat tabel 2.

Tabel 2. Peningkatan Hasil Belajar Peserta Didik

\begin{tabular}{|l|c|c|c|}
\hline & $\begin{array}{c}\text { Pra } \\
\text { Siklus }\end{array}$ & Siklus I & Siklus II \\
\hline $\begin{array}{l}\text { Jumlah } \\
\text { Peserta Didik }\end{array}$ & 38 & 38 & 38 \\
\hline $\begin{array}{l}\text { Rata-rata } \\
\text { nilai }\end{array}$ & 42,89 & 85,53 & 90,53 \\
\hline Tuntas & 0 & 32 & 33 \\
\hline $\begin{array}{l}\text { Persentase } \\
\text { Ketuntasan }\end{array}$ & $0 \%$ & $84,21 \%$ & $86,84 \%$ \\
\hline
\end{tabular}

Tabel 2 menunjukkan bahwa terjadi peningkatan persentase ketuntasan per siklusnya. Pada pra siklus persentase ketuntasan sebesar 0\%, pada siklus I sebesar $84,21 \%$ dan pada siklus II sebesar $86,84 \%$.

Dari data yang diperoleh maka minat belajar dan hasil belajar peserta didik menunjukkan adanya peningkatan dari siklus I ke siklus II. Dapat disimpulkan bahwa pembelajatan matematika materi segiempat dan segitiga menggunakan model PAIKEM Gembrot dapat meningkatkan minat dan hasil belajar.

\section{SIMPULAN}

Berdasarkan hasil penelitian yang telah dilaksanakan, dapat disimpulkan bahwa model PAIKEM Gembrot dapat meningkatkan minat dan hasil belajar matematika materi segiempat dan segitiga pada peserta didik kelas VII-D MTs Negeri Salatiga.

Minat belajar peserta didik setelah diterapkan model pembelajaran PAIKEM Gembrot terjadi peningkatan persentase minat peserta didik kategori tinggi dari Pra-Siklus didapat 13,16\%, siklus I 


\section{Jurnal Hipotenusa, 1 (1), Desember 2019}

Esti Rahayuningtyas, Muhammad Istiqlal

$36,84 \%$, dan siklus II 65,79\%. Peningkatan persentase minat kategori tinggi dari prasiklus kel siklus I yaitu $23,68 \%$, dan dari siklus I ke siklus II yaitu $28,95 \%$.

Hasil belajar peserta didik setelah diterapkan model pembelajaran PAIKEM Gembrot terjadi peningkatan dari PraSiklus terdapat $0 \%$ peserta didik tuntas, siklus I $84,21 \%$ peserta didik tuntas, dan pada siklus II terdapat $86,84 \%$ peserta didik tuntas. Peningkatan peserta didik yang tuntas belajar dari Pra-Siklus ke Siklus I adalah $84,21 \%$ dan Siklus I ke Siklus II adalah 2,63\%.

\section{DAFTAR PUSTAKA}

Ahmadi, I K dan Amri, Sofan. 2011. PAIKEM GEMBROT. Jakarta: Prestasi Putaka.

Ansor, Ahmad Saiful. 2015. PENERAPAN Model PAIKEM Gembrot untuk Meningkatkan Prestasi Belajar Matematika Peserta Didik Kelas VIII C SMP Islam Sunan Gunung Jati Ngunut Tulungagung Tahun 2015. Skripsi tidak diterbitkan. Tulungagung: Jurusan Tadris Matematika IAIN Tulungagung.

Arifin, Zaenal. 2017. Evaluasi Pembelajaran. Bandung: PT. Remaja Rosdakarya.

Arikunto, Suharsimi. 2010. Prosedur Penelitian Suatu Pendekatan Praktik. Jakarta: Rineka Cipta 2014. Prosedur Penelitian Suatu Pendekatan Praktik. Jakarta: Rineka Cipta.

Arikunto, Suharsimi dkk. 2015.Penelitian Tindakan Kelas. Jakarta: Bumi Aksara.

Azwar, Saifuddin. 2007. Metode Penelitian. Yogyakarta: Pustaka Belajar.
2010. Metode Penelitian. Yogyakarta: Pustaka Belajar.

Depdiknas. 2006. Permendiknas No. 22 Tahun 2006 Tentang Standar Isi. Jakarta: Depdiknas.

Djamarah, Syaiful Bahri. 2002. Strategi Belajar Mengajar. Jakarta: Rineka Cipta.

2005. Guru dan Anak dalam Interaksi Anak Didik. Jakarta: Rineka Cipta.

Mayura, Evi. 2014. Hubungan Antara Minat Belajar dengan Prestasi Belajar Siswa Kelas VI di SD N 20/1 Jembatan Mas. Skripsi tidak diterbitkan. Jambi: Fakultas Keguruan Universitas Jambi.

Octavia, Feni. 2016.Peningkatan Keaktifan Belajar dan Hasil Belajar Matematika pada Materi SPLDV bagi Siswa Kelas VIII G SMP Negeri 7 Salatiga Melalui Model PAIKEM Gembrto Semester II Tahun Ajaran 2015/2016. Skripsi tidak diterbitkan. Salatiga: Fakultas Keguruan dan Ilmu Pendidikan Universitas Kristen Satya Wacana Salatiga.

Purwanto, Ngalim. 2009. Ilmu Pendidika Teoritis dan Praktis. Bandung: PT. Remaja Rosdakarya.

$$
\text { 2011. Psikologi }
$$

Pendidikan. Bandung: PT. Remaja Rosdakarya.

Rohwati, M. 2010. Penggunaan Education Game untuk Meningkatkan Hasil Belajar IPA Biologi Konsep Klasifikasi Makhluk Hidup. Jurnal Pendidikan IPA Indonesia. Semarang: Unnes.

Saleh, Abdul Rahman. 2004. Psikologi Suatu Pengantar dalam Perspektif Islam. Jakarta: predana Media. 
Sari, Ressa Arsita. 2014. Hubungan Minat

Belajar Siswa dengan Hasil

Belajar IPS di SD GUGUS 1

Kabupaten Kepahiang. Skripsi tidak diterbitkan. Bengkulu: Program Studi Pendidikan Guru Sekolah Dasar Universitas Bengkulu.

Siagian, Roida Eva F. 2015. Pengaruh Minat dan Kebiasaan Belajar Siswa terhadap Prestasi Belajar Matematika. Jurnal Pendidikan Matematika. Jakarta: Universitas Indraprasta PGRI.

Slameto. 2010. Belajar dan Faktor-faktor yang Mempengaruhi. Bandung: PT. Remaja Rosdakarya.

Sudjana, Nana. 2009. Penilaian Hasil Proses Belajar. Bandung: PT. Remaja Rosdakarya

Suryabrata, Sumadi. 2017. Psikologi Pendidikan. Jakarta: Raja Grafindo Persada.

Susilo. 2007. Penelitian Tindakan Kelas. Yogyakarta: Pustaka Book.

Wiliasari, Herlina Fenty A. A. 2011. Penerapan Model PAIKEM Gembrot dalam Pembelajaran Mengapresiasi Karya Seni Rupa Terapan Nusantara untuk Meningkatkan Proses dan Hasil Belajar Kelas X 2 SMA Negeri 1 Durenan Trenggalek Semester Genap 2010.2011. Jurnal Pendidikan. Malang: Universitas Negeri Malang. 